\title{
The poetry of Being Present! An analysis of Transcendental thought in the work of Stuart Saunders Smith
}

\author{
José Augusto Duarte Lacerda (Universidade Federal do Mato Grosso, Cuiabá, Mato Grosso, Brasil)
} zecalacperc@gmail.com

\begin{abstract}
New England composer Stuart Saunders Smith (1948) is immersed in a milieu that echoes the American Transcendentalist movement. Transcendentalist figures, like Emerson and Thoreau, discussed notions also emphasized by Smith's: autonomy, intuition, experience, self-reliance, self-actualization, pacifism, and a claim that each person is part of a single universal spirit-Oneness. This article focuses on how such notions reflect in Smith's compositional process and how two particular aspects, pacifism and Oneness, reflect in the music that emerges from this process. In Smith's compositional process, experience, "filtered" through intuition, is more important than precompositional systems. Therefore, his work is seen as antithetical to formalism. Oneness is achieved by leveling the roles of composer, performer, and audience. This procedure appears particularly in his trans-media systems, mobile compositions, and co-existence pieces. Pacifism emerges in his use of intricate rhythms. These stances suggest Smith's music as part of a lineage of thought that traces back to the Transcendentalists: the idea of facing tradition critically while upholding free agency as the primary source of artistic creation.
\end{abstract}

Keywords: Stuart Saunders Smith; Transcendentalism; contemporary music; percussion.

\section{A poética em Being Present! Uma análise do pensamento transcendental no trabalho de Stuart Saunders Smith}

Resumo: O compositor da Nova Inglaterra, Stuart Saunders Smith (1948), está imerso em um ambiente que ecoa o movimento Transcendentalista americano. Figuras Transcendentalistas, como Emerson e Thoreau, discutiram noções também enfatizadas por Smith: autonomia, intuição, experiência, autoconfiança, autorrealização, pacifismo e uma afirmação de que cada pessoa é parte de um único espírito universal - Unidade. Este artigo enfoca como essas noções refletem no processo de composição de Smith e como dois aspectos particulares, o pacifismo e a Unidade, refletem na música que emerge desse processo. No processo de composição de Smith, a experiência "filtrada" pela intuição é mais importante que quaisquer sistemas pré-composicionais. Portanto, seu trabalho é visto como antitético ao formalismo. A Unidade é alcançada nivelando os papéis de compositor, performer e público. Este procedimento aparece particularmente em seus sistemas transmídia, composições móveis e peças de coexistência. O pacifismo surge no uso de ritmos intricados. Essas posturas sugerem a música de Smith como parte de uma linhagem de pensamento que remonta aos Transcendentalistas: a crítica à tradição, e a livre agência como a fonte primária da criação artística.

Palavras-chave: Stuart Saunders Smith; Transcendentalismo; não-teleologia; música contemporânea; percussão.

Near the end of the nineteenth century, American author Octavius B. Frothingham argued that New England was a place where "the sentiment of individual freedom was active" $(1876,107)$. New Englanders, Frothingham added, acknowledged "that it takes all sorts of people to make a world, and the many minds of the many men were respected" (1876, p. 107). New England was, therefore, an environment primed for the birth and flourishing of the American literary and philosophical movement called Transcendentalism, which has arguably helped shape American society since the 1830s. Born and raised in New England over a century after the apex of this movement, composer Stuart Saunders Smith (b. 1948, Portland, ME) was immersed in an environment that exemplified-and continues to exemplify-the cultural impact of Transcendentalism.

Smith started his music studies at the age of six. His teacher, Charles Newcomb, "a retired vaudeville drummer," trained the young student in music reading and percussion techniques-especially drumset-and motivated him to improvise and compose music. (SMITH in TRAXLER, no p.) As a teenager, he became increasingly interested in jazz music, participating in combos that focused on free improvisation. At this time, Smith and his 
bandmates were not aware of labels such as free jazz (SMITH and GOLDSTEIN, 1998, p. 196-197). In 1966, he attended the Berklee College of Music with intentions to refine his jazz drumset skills. Smith was already interested in American modernist poetry, having written "sound poetry, chance poetry, and free verse, although he was never formally exposed to any of these forms and had no context or terminology for the work" (WELSH, 1995, p. xxvii). His taste for poetry developed into an interest of using spoken word in a large bulk of his repertoire, starting with his first opus Poems I, II, III (1971) for brake drums and narrator. From 1967 until 1972, he pursued undergraduate and master's studies in percussion performance with Alexander Lepak at the Hartt School of Music. Interested in refining his compositional skills, Smith also studied with composer Edward Diemente while pursuing his master's degree. This growing interest in composition led him to pursue doctoral studies in composition at the University of Illinois at Urbana-Champaign (UIUC). Headed by mentors such as Salvatore Martirano, Herbert Brün, and Ben Johnston, UIUC's composition studio was one of the most vibrant in the United States in the 1970's. In spite of his awareness of different musical trends, such as American experimentalism and EuroAmerican serialism, Smith developed an idiosyncratic compositional style, particularly aided by his constant philosophical debates with Brün. His compositional identity was already mature when he composed the Links Series of Vibraphone Essays, still as a student in Illinois. This widely performed series of three solo pieces was commissioned by Smith's wife-music publisher and editor Sylvia Smith-and premiered by UIUC's percussion professor Tom Siwe in 1974. In the next two decades, the Links series grew to eleven pieces, some of them featuring other instruments alongside the vibraphone.

Ever since the composition of Links, Smith has frequently written for the vibraphone. Even though the composer's repertoire is comprised of diverse formations of solo and chamber music, percussion music has constituted the largest bulk of his output with the vibraphone holding a special place in his heart. Composing for the solo vibraphone has become analogous to writing entries in his life diary. Notably, percussionist Steven Schick compared the Links series to the journals of Thoreau (SCHICK, 2009, p. 5) but I consider this sentiment applicable to Smith's entire work. Each of his pieces can be well described as a journal entry that tells memories of his musical experiences. During Smith's compositional process, experience-based aural imprints manifest as melodies and rhythms that arise intuitively, without logical pre-planning. Smith has frequently implied that true art is the result of collaboration between knowledge gained through experience and intuition. The idea of intuition refers to Kantian reason rather than to the compositional systems learned in academia-or from "conditioning," as he likes to say. Smith has had a long academic career; he taught at the University of Maryland Baltimore County (UMBC) from 1975 until 2011. Nonetheless, he has always believed that in the art-making process, the experience gained in academia has to be rooted by intuition. So I contend that in Smith's compositional process, a kind of "filtered" experience is always paramount to conditioning. His intuition heads this process, by letting his musical, familial, political, and spiritual backgrounds, come across in the music that emerges from the process.

Although the Transcendentalism flourished a hundred years before Smith's birth, its ideas have become a part of New England's and Smith's consciousness. While various literary figures of the region have informed Smith's work, it is particularly the Transcendentalist authors that dialogue with much of the ethos behind his music, his writings on music, his compositional process, and his beliefs regarding the social role of the artist. The term "transcendentalism" refers to a philosophical attitude that traces back to German idealism, frequently tied to the philosopher Immanuel Kant (1724-1804) (BERMAN, 
1994, p. 15). Generally speaking, transcendental philosophy assumes that knowledge is not acquired empirically; rather, knowledge depends on a kind of reason that transcends "the limitations of thought imposed by empiricism" (BERMAN, 1994, p. 15). In Kantian philosophy, reason is the human "supreme faculty," a development of Descartes' doctrine of "innate ideas" (FROTHINGHAM, 1876, p. 14-22). Reason originates intuition, subordinates all human faculties, and shapes our understanding of the universe, divinity, and reality (FROTHINGHAM, 1876, p.14-22). The ideas of Kant and of the successive German idealists informed the Transcendentalist notion of knowledge, humanity, divinity, and the universe.

In the nineteenth century New England, Kantian philosophy was absorbed by the strong religious roots of the region. In short, the Transcendentalist movement that emerged from this combination of Kant and Christianity understood each person as a partaker of a single universal spirit (EMERSON, 1989, p. 399) — to which this article refers as Oneness. However, most importantly, this "Oneness" did not manifest in a homogeneous mass of ideas and individuals. Rather, it meant that each person's divine worth granted them autonomy of thought and agency. To further refine this provisional definition of Transcendentalism, it is necessary to identify an array of notions that recur in the works of the two authors who are still accepted as Transcendentalism's main pillars: Ralph Waldo Emerson and Henry David Thoreau. Their works consistently imply or directly refer to keywords such as Oneness, innate knowledge, intuition, experience, thought autonomy, self-reliance, coexistence, and pacifism. Within this article, Section 1 attempts to contextualize the aforementioned terms to provide a basis for my later discussion. Section 2 presents contrasting notions of transcendentalism in Western art and music. Finally, Section 3 surveys Transcendentalist ideas reflected in Smith's compositional process.

\section{KEY PRINCIPLES FROM TRANSCENDENTALISM}

\subsection{Experience and innate knowledge}

The official start of Transcendentalism is 1836 in Concord, Massachusetts, where Ralph Waldo Emerson and others founded the Transcendentalist Club. An important motivation Transcendentalism's inception was the disillusionment of the club's members with the Protestant religion known as Unitarianism. In general, Unitarians were religious figures who followed the ideas of empiricist philosopher John Locke, who believed that all knowledge originated from sensation and perception alone (BERMAN, 1994, p. 11).

Conversely, Transcendentalists were informed by Kant's notion of the human knowledge as innate (SACKS, 2003, p. 8). According to Art Berman, transcendental philosophy received this name because it sought to transcend the boundaries of knowledge imposed by empiricism (BERMAN, 1994, p. 15). For the New England Transcendentalists this transcendence meant that "reason" (understood as intuition in this context) filtered experience, so that any knowledge acquired was challenged rather than blindly accepted. As Emerson asserted (1989, p. 395):

The great distinction between teachers sacred or literary,-..., -is, that one class speak from within, or from experience, as parties and possessors of the fact; and the other class, from without, as spectators merely, or perhaps as acquainted with the fact on the evidence of third persons. It is of no use to preach to me from without.

Like Locke, the Unitarians supposedly spoke "from without," as "spectators" of the evidences unveiled by others. On the other hand, the Transcendentalists supposedly 
spoke "from within," letting intuition function as a filter that translated personal experience into idiosyncratic knowledge. In The American Scholar, Emerson coined the term "Man Thinking," which parallels his idea of a person who speaks "from within" and who relies on his own perception of truth as paramount to the truth presented in books. This notion showed Emerson's concern with how the excess of specialization in the early industrial times of America tended to transform "man into a thing" (EMERSON, 1971, p. 53). In this process, the scholar was the only segment of society given the chance to exercise intellectual thinking. For Emerson, the average scholar was becoming a "parrot" who merely echoed principles imposed by academia: "In the right state, he [the scholar] is, Man Thinking. In this degenerate state, when [he is] the victim of society, he tends to become a mere thinker, or, still worse, the parrot of other men's thinking" (EMERSON, 1971, p. 53). Emerson's debate does not lie in attacking intellectualism. Rather, Emerson defends the idea that knowledge is only valid if it yields the individualization of the experience from which it originates.

\subsection{Self-reliance and autonomy of thought}

The doctrine of innate knowledge inspired Emerson to develop a discourse in defense of self-reliance, according to which men were entitled to individually shape their own character, intellect, set of beliefs, and artistry through personal experience rather than the experience of someone else: "Insist on yourself; never imitate. Your own gift you can present every moment with the cumulative force of a whole life's cultivation; but of the adopted talent of another, you have only an extemporaneous, half possession" (EMERSON, 1989, p. 278-279).

In Self-Reliance, Emerson sought his audience's free agency and freethinking. And such were the ethos behind the Transcendentalist movement. Most notably, Thoreau emphasized these aspects to the point of writing a treatise about their practice-Walden. Throughout Walden, Thoreau raised awareness that the nineteenth century American was discouraged from exercising intellectual autonomy and believed that living upon materialistic values was the only choice: "When we consider what, ..., is the chief end of man, and what are the true necessaries and means of life, it appears as if men had deliberately chosen the common mode of living because they preferred it to any other. Yet they honestly think there is no choice left" (THOREAU, 2006, p. 14).

Thoreau's statement shows his disillusionment with a society that suppressed thought autonomy and gave individuals the idea of a complete absence of choice.

\subsection{Inner divinity and Oneness: the universal soul}

Both the belief in man's divine attributes and the existence of unity that bonds every life shaped the Transcendentalist spiritual consciousness. These creeds are particularly explicit in Emerson's (1989, p. 399), which refers to a universal soul composed of all souls:

The Supreme Critic on the errors of the past and the present, and the only prophet of that which must be, is that great nature in which we rest, as the earth lies in the soft arms of the atmosphere; that Unity, that Over-soul, within which every man's particular being is contained and made one with all other; . . . . Only by the vision of that Wisdom can the horoscope of the ages be read, and by falling back on our better thoughts, by yielding to the spirit of prophecy which is innate in every man, we can know what it saith. 
One striking notion in this passage is that it links Oneness to man's intellect ("Only by the vision of that Wisdom . . . we can know what it saith"). Because the whole and the individual are a priori apart, Emerson infers that there is a precedence of the inner over the outer world, as each individual soul becomes the emanatory agent of the "Over-soul" (SHULTIS, 2013, p. 11). A second key feature of this passage from Emerson is its mystical implication: Christian likeness to God becomes inner divinity.

\subsection{Pacifism}

Pacifism is part of Transcendentalism's essence, because the very idea of Oneness is antithetical to war. In simple terms, no one harms someone else if one believes that the other is a part of you. In War, Emerson (1909, p. 193-194) relates the idea of reaching peace to a "high stage" in which man has realized his condition of Oneness ("common soul of all men”):

At a certain stage of his progress, the man fights, if he is of a sound body and mind. At a certain higher stage, he makes no offensive demonstration, but is alert to repel injury, and is of an unconquerable heart. At a still higher stage, he comes into the region of holiness. ... . But, being attacked, he bears it and turns the other cheek as one engaged, throughout his being, no longer to the service of an individual but to the common soul of all men.

Pacifism for Emerson does not preclude his idea of self-reliance, but is a consequence of honoring the "universal spirit."

\section{TRANSCENDENTALISM IN MUSIC}

\subsection{Transcendentalism versus formalism}

In general, the term "transcendentalism" in Western music has followed two main paths: a general notion of transcendentalism in relation to twentieth-century music (e.g. in Leonard B. Meyer's Music, the Arts, and Ideas) and a more New England-specific model of musical Transcendentalism, as developed by scholars such as Christopher Shultis. The latter often emphasize the influence of Emerson and Thoreau on the work and life of Charles Ives and John Cage, respectively.

Meyer proposes a tripartite construct to explain the arts in the twentieth century, composed of "formalism," "transcendentalism," and "traditionalism." The motivation behind traditionalism is what Meyer calls "content," which refers to the work's representational value. Therefore, the goal of a traditionalist piece of art is to symbolically convey meaning. "End" is a word that describes traditionalism. Formalism, which Meyer understands as an intermediary of traditionalism and transcendentalism, focuses on the "means." "Form" and "procedure" are some words that describe formalism. There are abundant examples in the twentieth century, but the post-war compositions aligned with the incipient stages of the Darmstadt Summer Courses are definitive, such as Pierre Boulez's Structure Ia. Finally, transcendentalism focuses on "materials." The term "sensory experience" accurately describes Meyer's concept of transcendentalism (MEYER, 1969, p. 214-222).

The agenda of formalism, according to Meyer (1969, p. 157), contemplates objectivity and impersonality: 
The concept of art as objective and impersonal is obviously related to the current tendency toward formalism. The artist, like the scientist, 'discovers' and no longer 'creates' by expressing himself; he constructs. Music becomes allied to formal logic of mathematics. The novel becomes a kind of research or a species of problem solving.

Conversely, Meyer's concept of transcendentalism implies that sensory experiences should be understood for what they are, without the distortions of logic: "According to transcendentalism, the constructs of analytic formalism-whether in the arts or in the sciences-misrepresent and distort our understanding of the world. What are truly real, and really true, are concrete particular sense experiences." In other words, transcendentalism sees no distinction between art and nature. The sensory aspects of art-aural, tactile, or visual-have to be merely experienced for what they are (i.e. as natural phenomena).

In music, Meyer's transcendentalism implies the notion that the composer and the audience should coexist with aural phenomena, avoiding the imposition of extraneous logics to sound. Composer John Cage (1991) in particular argued that sounds should be regarded "just as they are:"

People expect listening to be more than listening. And sometimes they speak of inner listening, or the meaning of sound. When I talk about music, . . . I'm talking about sound that doesn't mean anything. That is not inner, but is just outer. And they say, these people who finally understand that say, "you mean it's just sounds?" To mean that for something to just be a sound is to be useless. Whereas I love sounds, just as they are, and I have no need for them to be anything more. I don't want sound to be psychological. ... I just want it to be a sound.

By considering sounds to be experienced as "just sounds," Cage implies that no intellectual inference is necessary to interpret them. Rather, one must accept sounds for what they are. Cage's statement is an indication of his coexisting attitude toward aural experience and a confirmation to Meyer's definition of "transcendentalism:" artistic emphasis on "materials" (sounds). Alternatively, artistic emphasis on process and form suggests formalism. Hence, as Art Berman has stressed (1994, p. 69), the central question of formalism becomes "how."

\subsection{Emerson/lves versus Thoreau/Cage}

Meyer's ideas of transcendentalism and formalism imply antagonistic attitudes of the human intellect in relation to nature. While transcendentalism implies nonduality (i.e. humanity and nature coexist without hierarchy), formalism implies duality (i.e. man's intellect determines the definition of nature). In Silencing the Sounded Self, Christopher Shultis created a bipartite construct that is strikingly similar to Meyer's, with the exception that Shultis does not contemplate formalism. Rather, Shultis utilizes terms such as "coexistence" or "non-dualism" as opposed to "control" or "dualism." The crucial difference here is that Meyer not only relates formalism to dualism, but also relates it to objectivity and impersonality. Despite the similarities of both constructs, while Meyer's "transcendentalism" can translate directly into Shultis' "non-dualism," his "formalism" does necessarily translate into Shultis' "dualism." Even though Emerson and composer Charles Ives supposedly embraced a dualistic view of reality, they do not fit into Meyer's description of formalism because individual expression, not process or rational logic, was predominant in their discourses. Moreover, the concept of symbol-what Meyer (1969 p. 213) calls "content" or "representational significance"-is essential to Ives' and Emerson's work and extraneous to formalism, as previously discussed. Therefore, if Meyer's construct were 
to be used in reference to Emerson and Ives, they would not be formalists but traditionalists. On the other hand, Shultis' hypothesis for Thoreau and composer John Cage better suits Meyer's concept of transcendentalism.

For Shultis, the two contrasting attitudes amongst American artists with respect to self and nature can be traced back to Emerson and Thoreau: Emerson exercised a "controlling" attitude towards nature, whereas Thoreau exercised a "coexisting" attitude (SHULTIS, 2013, p. xviii). Such opposition is also reflected in the American musical experimentalism of the twentieth century, of which Ives and Cage represent different generations. Emerson's "controlling" attitude parallels Ives's views on music, whereas Thoreau's "coexisting" attitude is equivalent to Cage's views on music. Using this dichotomy to explain the American experimentalist tradition, Emerson and Ives emphasize a goal-oriented character in their (musical or literary) experiments, while Thoreau and Cage focused on "open-ended" experiments. While the goal-oriented perspective involves a test of pre-conceived truth, the open-ended perspective encourages a discovery of something unknown (SHULTIS, 2013, p. 4). In other words, the goal-oriented perspective focuses on a purpose, whereas the openended perspective focuses on the process.

For Shultis, Emerson believes that "thought is always prior to the fact; all the facts of history preexist in the mind as laws" (SHULTIS, 2013, p. 10). So the disparity between Emerson and Thoreau is that for Emerson the universe is formed by "Nature and the Soul," whereas for Thoreau the fact that the soul is part of nature is already granted (SHULTIS, 2013, p. 11). Emerson believes that man and nature are unified only through symbol, an intellectual act that implies precedence of man over nature. Emerson-and later, Ives-identify art as capable of unifying both [humanity and nature] via the use of a particular symbolic practice called transcendental correspondence" (SHULTIS, 2013, p. 9). For them, although man and nature are one, man's human intellect-manifested through the arts, for instanceunifies himself and nature via "transcendental correspondence." If humanity and nature are not unified a priori, man's "controlling" self is needed so as to unify them. So, according to Shultis' take on Emerson, the goal of Emerson's "experiment" is the unification of man and nature in a universe that is a priori dualistic. This was also Ives's goal, as indicated in his Essays Before a Sonata, which entails his intellectual impetus for unification.

After Essays, Ives was destined to have his music tied to Transcendentalism. Like Emerson, he is frequently referred to as an early case of American experimentalism, because he attempted compositional techniques unique for his time, such as the use of clusters, pervasive quotations, and frequent juxtaposition of various musical styles. Ives's experimental compositional strategies, especially his use of quotation and program, were a means to achieve the Transcendentalist universal unity. Because Ives uses these strategies to reference "local color" (ragtime, church hymns, and wind bands), he understands his Transcendentalism in terms of unifying the "local" with the "universal." In Ives' work, the referenced cultures become central rather than mere exoticism. Although Ives' work is strongly characterized by "local color," he is critical of its use for the mere sake of audience approval:

It is evidenced in many ways-the sculptors' over-insistence on the 'mold,' the outer rather than the inner subject or content of his statue overenthusiasm for local colorover-interest in the multiplicity of techniques, in the idiomatic, in the effect as shown, by the appreciation of an audience rather than in the effect on the ideals of the inner conscience of the artist or the composer (IVES, 1962, p. 162-163). 
Ives recurrently uses the term "manner" in opposition to "substance" to further discuss this "overenthusiasm" for compositional artifices that merely adorn a piece of music or show instrumental virtuosity. For him, "manner" does little but mask the supposed hollowness of a work. Conversely, he understands that his use of "local color" evidences Transcendentalist attitude, because it is an expression of speaking from "within" and not from "without” (EMERSON, 1989, p. 395). For Shultis, "it is content, 'the substance' of his quotations, that is of interest here and his use of quotations goes beyond the notion of merely representing outside experience" (SHULTIS, 2013, p. 26).

Thoreau and Cage form the other side of the dichotomy proposed by Shultis, as they understand the universe as unified $a$ priori. Their attitude toward reality implies that no intellectual action or symbol is needed to unify man and nature. As part of this "nondualistic" view of reality, there is a "coexisting" instead of an "imposing" attitude toward natural phenomena, as Cage states: “. . . I love sounds, just as they are, and I have no need for them to be anything more. I don't want sound to be psychological. . . . I just want it to be a sound" (CAGE, 1991). Cage's statement suggests that his music does not attend to any goal other than the aural experience. The same could be said about Thoreau's experiment at Walden Pond: "I went to the woods because I wished to live deliberately, to front only the essential facts of life, and see if I could not learn what it had to teach, and not, when I came to die, discover that I had not lived. I did not wish to live what was not life, living is so dear; nor did I wish to practice resignation, unless it was quite necessary" (THOREAU, 2006, p. 97). For Shultis, this statement proves that the motivation of Thoreau's experiment was not a hypothesis, but a question: "What is and what is not life?" (SHULTIS, 2013, p. 30).

Because Thoreau's experiment has no goal or intellectual impetus towards testifying any sort of unification, Shultis understands Thoreau's work as open-ended, like Cage's. Man and nature, like life and art, are one a priori.

While Shultis does not argue that Ives or Cage represent a direct continuation of Transcendentalist ideas via Emerson and Thoreau, he places the two composers in an important lineage of American experimentalists who owe a debt to the Transcendentalists. Stuart Saunders Smith fits in this same lineage.

\section{TRANSCENDENTALISM IN SMITH'S MUSIC}

\subsection{Confronting Transcendentalism and formalism: intuitive art and academic art}

In order to explain Smith's music, I have adapted both the previously discussed constructs, proposing that capital "T" Transcendentalism (synthesizing aspects of both traditionalism and transcendentalism) is antithetical to formalism. With regard to formalism, I share the concepts of both Meyer and Art Berman, who infer that formalism seeks to minimize personality and emphasize procedure. According to Berman, each formalist work is intended to be objectively analyzed, or to ratify a system: "To each body of work a formalist theory is appended, which the work is both to ratify and exemplify" (BERMAN, 1994, p. 71) This construct will be essential in understanding Smith's work as reflecting important concepts of Transcendentalism while eschewing formalism, because his work is never intended to be the object of logical analysis, but to be intuitively experienced.

Smith's denial of formalism starts from his refusal to apply pre-compositional systems in his music. He believes that the use of formulae and charts prevent the composer's own voice to manifest itself. Rather, by relying on intuition, the composer is able to channel individualized experience. Smith's belief relates to Emerson's concepts such as speaking "from within," as implied in Smith's poem-essay Composing Thoughts: 


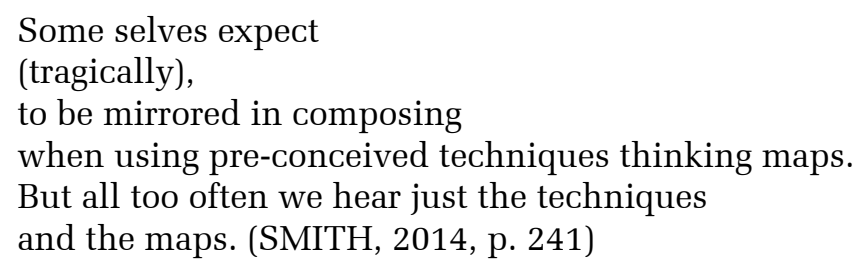

The absence of noticeable "maps" in Smith's music indicates his denial of precompositional systems, thus paralleling Emerson's attitude toward books, as shown in The American Scholar: "Books are the best of things, well used; abused, among the worst. . . They are for nothing but to inspire. I had better never see a book than to be warped by its attraction clean out of my own orbit, and made a satellite instead of a system" (EMERSON, 53, p. 1971) For Emerson, Unitarians had become "parrots" rather than free thinkers who used books only for "inspiration," posing possibilities that books may become an object of alienation if used uncritically. Similarly, for Smith, when logic is "abused" (i.e. detached from personal experience), it does not constitute worthwhile knowledge: "When man is alienated from his inner world and from living in the senses, then man makes choices only according to logic and reason, which are tools at the service of any point of view. Logic and reason must be rooted in values made in the senses or they become lethal."(SMITH, 1984, p. 277). For Stuart, the music created through systematic thinking is divorced from emotions and nature, thus artificial and dissociated from one's inner world. In academic music-making, the alienation from one's inner world may reflect specifically in the use of pre-compositional systems, which Smith disproves.

Smith says that composers who use pre-compositional systems try "to attain a socalled unconditioned music" (SMITH, 1994, p. 215). The use of twelve-tone technique, or any kind of systematic thinking in composition, aims to create music that is "unconditioned" or supposedly dissociated from musical tradition; however, these methods actually condition the occurrence of features such as pitch, dynamics, texture, and articulation to predetermined settings. Smith refers to some academic music as "so-called unconditioned," because they are often conditioned to the historically-accepted compositional techniques taught in academia. For Smith, the true role of education opposes academic training:

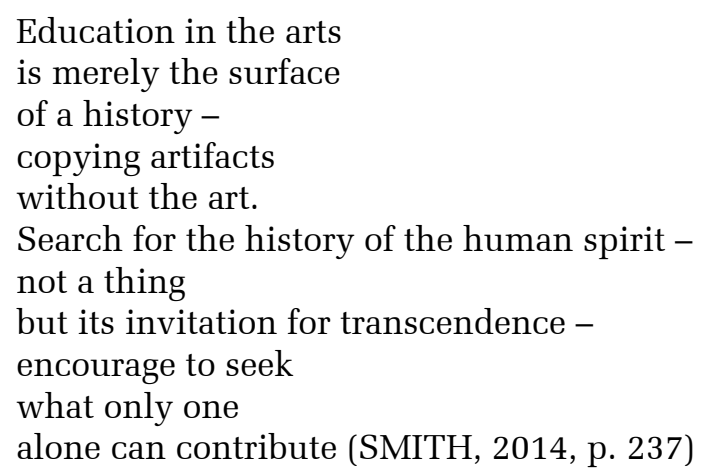

Because Smith believes that academia frequently tends to suppress the self, his disavowal toward academic conditioning is akin to that of Emerson's in The American Scholar. For Smith, the studies of harmony, counterpoint, and other theoretical aspects should provide the composer a base for wielding his or her intuition freely. On one hand, "there is the foundation and then the constructed house," while on the other hand, "there is the foundation and birds flying above it" (SMITH, interview with the author, 2013) While the former is Smith's metaphor for how formalist music is created, the latter is his metaphor for intuitive music. Smith understands that an artist becomes Emerson's "Man 
Thinking" only by "flying above" the foundation. Hence, acquired knowledge is a mere reference to be distilled through his intuition for Smith. A crucial premise of the creative artist then becomes to "automatically battle with his history" (SMITH, interview with the author, 2013), by avoiding academic conditioning and relying on innate knowledge. Even Smith's first three Links for solo vibraphone, written as a student at the University of Illinois, resist any purely objective analysis. It is true that as a developing composer, Smith used compositional devices such as simple forms, "retrograde technique, pitch construction based on permutations of major and minor seconds and thirds as outlined in the basic intervallic plan," and six somewhat frequent rhythmic gestures (WELSH, 1983, p. 84). However, as John P. Welsh has admitted, "no matter what some arbitrary system suggests as the next pitch(es) during the compositional process, the final decision ultimately rests with the composer's ear and intuition" (WELSH, 1983, p. 80). Welsh's statement testifies that the young Stuart Saunders Smith already sought to filter his academic tutelage via the reliance of "intuitive modes of knowing" (BERMAN, 1994, p. 13).

\section{2 "Smith, the man" and "Smith, the artist:" bridging Thoreau and Emerson}

As previously discussed, Smith's work gathers aspects of both traditionalism (focus on symbol) and transcendentalism (focus on the sensorial). Therefore, within Transcendentalism, Smith encompasses attitudes attributed to both Emerson and Thoreau. His ideas frequently reconcile dichotomies such as control and coexistence; individuality and collectivity; and dualism and non-dualism. When referring to these dichotomies present in Smith's work, it is useful to label each side of the spectrum in the following way to facilitate the understanding of his complex artistic world: "Smith, the man" indicates his Thoreauvian side, and "Smith, the artist," indicates his Emersonian side. However, it is never enough to emphasize that these two attitudes almost always coalesce: "Smith, the man" is indispensable because it informs "Smith, the artist" with life and political stances that are reflected in his music. Therefore, "Smith, the man's" emphasis on collectivity, coexistence, openness, and self-abnegation (which echo a trust in a universal spirit) is central to his artistic motivations.

"Smith, the artist" frequently emphasizes his creative mind over external conditioning, which partially implies a precedence of the inner over the outer. While "Smith, the man" (with a social sense of collectivity) understands the universe as unified a priori, "Smith, the artist" (or the idiosyncratic composer) searches for unity by writing music that symbolically creates this unity. "Smith, the man" is a Thoreauvian who sees intelligence everywhere, follows a vegan diet (an attitude of non-dissociation of humanity and the natural world), is a pacifist, and believes in a universal spirit; "Smith, the artist," is an Emersonian who understands that only the artistic mind can be the agent of unification. Smith bridges the supposed gap between Thoreau and Emerson because these two attitudes frequently act in concomitance during his compositional process. The way Smith's listening operates during his compositional process is an example of how Thoreauvian and Emersonian attitudes coalesce in his ideas about music.

"Smith, the man," demonstrates a kind of Thoreauvian "aural" self-abnegation, as he understands his need to listen to the "intelligence of the sounds" to let a composition arise. The attitude of recognizing intelligence in sounds is indicative of Smith's nondualistic side because the inner and the outer-the latter manifested as the sound-are acknowledged as part of a unity. Composing becomes a process of waiting because it is the sounds themselves that "teach" him this new composition: 
I compose by composing myself.

I listen.

I transcribe listening.

The sounds have an intelligence all their own; each

vibrates a story.

They teach me a new composition.

Composing is waiting. (SMITH, 2014, p. 246)

Smith understands this aural self-abnegation as an indispensable condition to let the composition arise naturally, as it helps free the compositional process from preconceived ideas:

\begin{abstract}
When I compose-I work at the piano-I try to be as quiet internally as possible, so that the musical ideas can emerge naturally, organically, from the body, from the spirit, from the mind. One has to get out of the way. This can be learned from Walden: if you pay attention, you see the intelligence of ants, you see the intelligence of the fish in the water, you see the intelligence of the trees. Well, it is the same with pitches. If you play a B-flat, and you listen, it is a vibration just like water is a vibration, just like the sky is a vibration, or our body is a whole bunch of different vibrations. And we listen to that, and we get one pitch, and then you get another pitch and another. (SMITH, interview with the author, 2014)
\end{abstract}

The notion that one is able to find intelligence anywhere in nature suggests that Smith's Thoreauvian side (emphasis on the sensorial and non-dualistic attitude) affects his music. Nonetheless, his self-abnegation is paradoxically joined with "Smith, the artist," by placing his creative mind as the primary source for his compositions. Therefore, "transcribing listening" does not only mean listening to the "intelligence of the sound," but it also means transcribing memories based on personal listening experiences-a process that acts concomitantly with Smith's “inner listening” (LACERDA, 2012, p. 40). When he states that pre-compositional systems ignore the "sound's intelligence manifested in the imprinted corporeal human inner ear to attain a so-called unconditioned music," (SMITH, 1994, p. 215) he provides an indication that inner listening works concomitantly with what he calls "sound's intelligence." He highlights the "imprinted corporeal human inner ear" as an indispensable condition for the recognition of the sound's intelligence (like Emerson's "vision of the Wisdom" as indispensable to the recognition of Oneness) (EMERSON, 1989, p. 399). In fact, Smith frequently determines the title of a piece before starting the composition, so that the title informs the sound of the piece: "Once I have a title, then I get out of the way and let the music emerge from that poetic universe" (SMITH, in MULLER, 2014, p. 9). Although Smith "gets out of the way," his creative mind inexorably plays a part in the process. Based on the "poetic universe" of the title, his "inner listening" inevitably participates in the process of choosing sounds that will supplement the "sound's intelligence." This enigmatic mode of composing indicates that although the unity of humanity and nature is a priori for Smith, the unity of life and art (or at least his life and his art) happens exclusively through symbol, as his intellectual input is always indispensable to the process.

\title{
3.3 Symbolizing unity
}

Smith's music symbolizes unity in two basic ways. First, his music unifies his own life with his art, which in turn happens in two manners: by drawing on "filtered" memories gathered from his aural experience through the process of inner listening and by conveying his life stances (notably pacifism) through his musical choices. However, conversely 
to Cage's non-dualism, Smith does not see life as an artistic experience. His attitude of conveying, for example, political beliefs through music suggests that unification happens only symbolically. Second, his music unifies composer, performer, and audience toward a unity akin to the Transcendentalist "Oneness." This is achieved through the musical application of concepts like openness and co-existence, as well as through discourse that alludes to this unification. The majority of his pieces convey unity in all the ways described: filtering experience, conveying life stances, and conveying Oneness.

\subsubsection{Unifying art and life}

\subsubsection{Filtering and framing memory}

Because Smith does not see art and life as a priori unified, his music becomes the catalyst for this unification by conveying his individualized experience that "frame" his aural memory. So terms such as "distilling" (or "filtering") and "framing" experience are essential to understand his compositional process. This process shows a basic contrast of Smith's idea of symbolic unity of art and life, as opposed to Cage's idea that art and reality are one. Smith's exclusively symbolic unification of life and art is well synthesized in the following statement. Here, Smith understands that while experiences may constitute music, life's hardships, for example, cannot be experienced as art:

With 4'33" Cage posited that life itself is art-that the traditional frame within which art was originally positioned was no longer valid. Further, when we notice, with an artistic mindset, anything can be art. ...

I find this position amoral. Is war, AIDS, third-world hardships, with a turn of the mind, to be experienced as art? To use an artistic mindset to experience real-life tragedy is, for me, unthinkable. ...

.... Art is distilled experience in a frame. Distilled experience gives the artwork such intensity that it literally holds our attention. The frame contains art in such a way that it heightens the experience by reining it into a small space. I find living in an artistic experience better than living in everyday life. Art's function is to bring us closer to the divine. (SMITH, in FALVO, 2011, p. 43)

Because art is, for Smith, experience distilled through artistic intellect, each of his musical works symbolizes his personal aural experience "in a frame." His music is neither a mere output of everyday life, nor a portrait of a lifestyle imposed by society. Smith believes that the attitude of facing all sounds as musical denies man's intellectual faculties. Rather, his music conveys intentional sounds-even if these sounds attend to a range of possibilities-so that it reflects his own "artistic experience." On the other hand, music that provides sounds that merely convey "everyday life" does not have the "intensity" to "hold our attention."

Smith's idea of how intuition filters-distills- experience is analogous to that of the Transcendentalists, particularly Emerson's (“... that one class speak from within, or from experience”) (EMERSON, 1989, p. 395). Smith refuses to compose merely from conditioning, because this attitude is indicative of speaking "from without," to use Emerson's term. Rather, by composing through individualized experience, Smith composes "from within." He "hears" inside-the sounds his memory gathered through experience-and lets the composition take form naturally, without preplanning: 
I compose through experience.

I watch a composition unfold.

Ideas have little space... .

Hear

Each day I see what will happen (SMITH, 2014, p. 226)

The attitude of each day waiting to "see what will happen," and letting intuition guide the process alludes to the Transcendentalist notion of experience as compliant to intuition. Here, Smith asserts that there is music in the human mind prior to any outer conditioning:

There is music,

constituted in the mind before learning.

To find what is constituted there

keep reaching

in the same time.

Then transcribe hearingmind,

Hearingmind a priori. (SMITH, 2014, p. 227)

Smith's neologism "hearingmind" alludes to his creative mind during the process of filtering experience (aural memory, in this case). In order to "transcribe hearingmind," he relies solely on the reminiscences of his listening memory, distilled through his idiosyncratic creative mind. This process is made possible through inner listening, an action that is, like the Transcendentalist innate knowledge, intended more to be "ignited" than to be logically understood (BUELL, 226, p. xviii). Through "inner listening," Smith intuitively turns memory into music. As Art Berman infers, "art is an exercise and a proof of intuitional knowledge and of its object and, consequently, of the idealist's general suppositions" (BERMAN, 1994, p. 18). How would Smith, then, define "inner listening?" The composer has applied this term frequently throughout his carrier. Its best definition is found in one of his writings:

I aspire to be a witnessing transcriber to a music which makes itself in the medium of listening. A listening that transcends self by consciously letting patterns emerge out of the sound's demand to take their own shape.

Obviously I am not talking about chance music or serial music. Chance music and serialism mechanically push sounds around, ignoring sound's intelligence manifested in the imprinted corporeal human inner ear to attain a so-called unconditioned music. Actually, such music is either without condition or merely conditioned. Serialism and chance treat sound as material outside the body-literally disembodied music. In each case the individual's corporeal sound-imprint is ignored. (SMITH, 1994, p. 215)

When Smith refers to a "listening that transcends self by consciously letting patterns emerge out of the sound's demand to take their own shape" (SMITH, 1994, p. 215), he not only defines "inner listening," but also expresses with precision his reconciliation of creative mind and aural self-abnegation. By emphasizing the sensorial (aurality) as a vital part of his compositional process, Smith suggests a Thoreauvian attitude. But the role listening takes in his compositional process does not downgrade into a non-scrutinized restatement of his listening memory; rather, only the sounds that are capable of leaving imprints in his "hearingmind" are brought about. Nonetheless, he does not want his "corporeal soundimprint," or his own realization of these sounds (via his idiosyncratic musical features), to be ignored. 


\subsubsection{Pacifism}

An important musical outcome of Smith's symbolic unification of life and art is his use of complex non-periodic rhythms. He ascribes his refusal to write regular rhythms to his pacifistic stance (which comes from his political and Quaker background) because he believes that regular rhythms recall military marching (SMITH and GOLDSTEIN, 1998, p. 188). As a result of this belief, Smith considers periodicity of any kind in music suggestive of war impetus. March-like music, as he (SMITH and GOLDSTEIN, 1998, p. 188) states,

is at the extreme end of a periodic-music continuum. March music is absolutely symmetrical. Its purpose is military or paramilitary. Other music like jazz, rock, various ethnic musics use periodicity each in quite different ways. What they have in common is the surface supremacy of the foot over the head. ... I find this a dangerous situation. There is a disconnect between our moral center and visceral selves. Therefore, I am not in favor of periodicity any longer in any form.

This statement corroborates that Smith's music avoids periodicity because periodicity emphasizes violent, animalistic behavior and because human intellectual condition is itself incompatible to war. As a result, Smith's music features an extremely complex rhythmic vocabulary, pervaded with non-periodic durational patterns often juxtaposed polyrhythmically.

The following example, As if Time Would Heal by its Passing (1991) for solo marimba, illustrates this assertion. The bracket of $9 / 7$ in the first system indicates nine consecutive notes with the speed of sixteenth-note septuplets. The polyrhythmic figures of this excerpt include broken figures of 5 against 4, 6 against 4, 7 against 6 , and others:

Fig. 1 - As If Time Would Heal by its Passing, by Stuart Saunders Smith, sixth page, lines 1 and 2
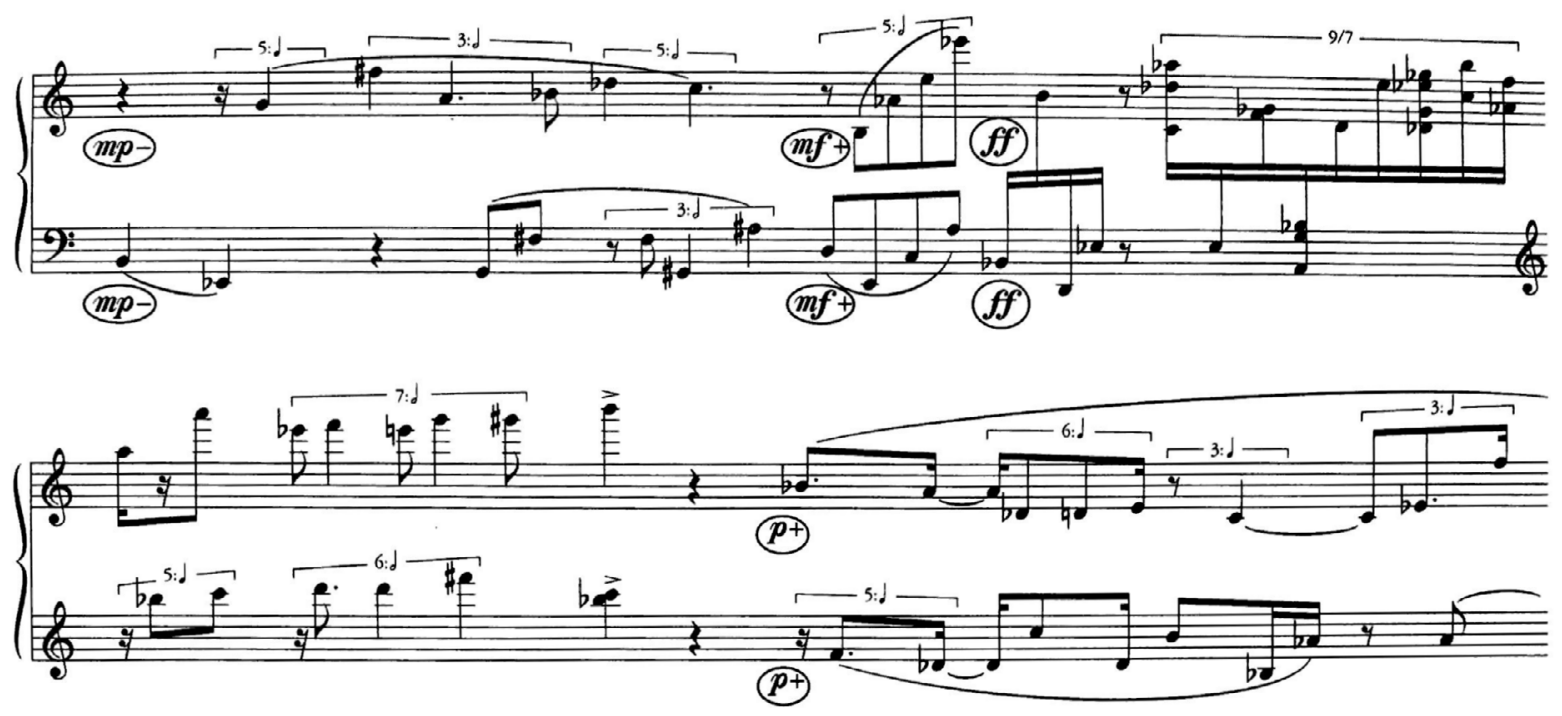

Copyright Sonic Art Editions. Used by permission of Smith Publications, Sharon, VT 05065 USA

In Walden, Thoreau recollects an incident in which he goes to jail for refusing to pay taxes to a "state which buys and sells men, women, and children, like cattle at the door of its senate-house" (THOREAU, 2006, p. 187). Smith sees this passage as evidence of the author's pacifistic stance, as he manifests his anti-slavery belief through a consciously non-violent stance (namely, refusing to pay his taxes). Smith says: "Civil disobedience is 
a bigger statement than violent disobedience. If you do violent disobedience against the war, you are starting a war on a smaller scale. It doesn't make sense. But if you have civil disobedience, by your action you are trying to teach the government what it should do." (SMITH, interview with the author, 2013). Hence, like Thoreau, Smith also believes that one must swim against the tide when institutions are morally wrong. At once, Smith's rhythmic intricacy therefore becomes a kind of "disobedience" against groove-based music and war, because refusing to surrender to society's belligerent impetuses is evidence of autonomous thinking. In Civil Disobedience Thoreau (BUELL, 2006, p. 259) also considered his pacifism a matter of freethinking, as he implies in this passage:

A common and natural result of an undue respect for law is, that you may see a file of soldiers, colonel, captain, corporal, privates, powder-monkeys, and all, marching in admirable order over hill and dale to the wars, against their wills, ay, against their common sense and consciences, .... They have no doubt that it is a damnable business in which they are concerned; they are all peaceably inclined. Now, what are they? Men at all? or small movable forts and magazines, at the service of some unscrupulous man in power?

When Thoreau writes that men while marching are doubtfully "men at all," he unveils the same issue as Smith: when composers focus on periodic rhythms, they glorify the "supremacy of the foot over the head" (SMITH and GOLDSTEIN, 1998, p. 188). The similarity of both statements also shows how both Thoreau and Smith advocate pacifism through non-violent acts, such as writing literature or music.

As discussed in the first chapter, the Transcendentalist anti-war stance was based on the existence of a universal soul. However, for Smith, the principle of Oneness manifests itself as openly anti-nationalistic more than in the case of the Transcendentalists. He says that he is longing for the day that "the word 'war' is no longer of any language's vocabulary" (SMITH, interview with the author, 2013). Looking towards the extinction of national boundaries, he affirms that only through the reduction of nationalism "to such a point that it does not matter what country you come from because we are all citizens of the world" that war will become an "obsolete relationship" between humans (SMITH, interview with the author, 2013). In War, Emerson gives a comparable pro-peace statement that, although applying it to the USA-specific context of the Transcendentalists: "If you have a nation of men who have risen to that height of moral cultivation that they will not declare war or carry arms, for they have not so much madness left in their brains, you have a nation of lovers, of benefactors, of true, great, and able men" (EMERSON, 1909, p. 195). The fact that, if compared to Emerson's call for peace, Smith's call for peace is posed in anti-nationalistic terms suggests that Smith's attitude is a development Emerson's concept of Oneness. The same could be said about Ives who, proposing a non-violent reaction to society's emphasis on accumulation of property, says: "That this limit of property be determined not by the voice of the majority but by the brain of the majority under a government limited to no national boundaries" (IVES, 1962, p.149). Both Ives and Smith develop a non-violent, Transcendentalist stance by merging pacifism with a practical vision of the universal spirit: anti-nationalism.

\subsubsection{Symbolizing Oneness}

This subsection features examples from three genres within Smith's music ("transmedia systems," "mobile compositions," and "co-existence music"), as well as a piece that fits in multiple genres, Here and There, to discuss how his work may symbolize Oneness. 


\subsubsection{Trans-media systems}

As open works, Smith's trans-media systems can be considered experimental. However, they bear an essential difference to the works of American experimentalists like Cage, James Tenney, or Alvin Lucier: the trans-media systems always preserve the personal imprint of the composer. In these systems, which include Return and Recall, Initiatives and Reactions, and Transitions and Leaps (1990), Smith celebrates a unified reality by inviting all the performers to be co-composers. Performers may include artists of different disciplines, such as music, dance, plastic arts, and theater. Smith got inspiration to write these systems from the Chinese Cultural Revolution, when the government of China demanded composers to write music collectively. This demand found a "ludicrous" solution: "one guy would compose the melody, another guy the harmony; one gal would orchestrate," as said by Smith in an interview featured in The Music of Stuart Saunders Smith, by John Welsh (1995, p. 139). Interested in this idea of collective composition, Smith found a different solution through the trans-media system.

The following example shows the first page of Transitions and Leaps. Its score does not present a finished composition; rather, it consists of graphic schemes-pictograms placed inside boxes-that provide instructions for performers to create their own music collectively or individually. Each group of symbols ("sub-systems") separated by a double breath mark indicates a different category of actions that the participants need to compose and perform. For instance, the first three groups of symbols indicate, from left to right, a "transitions" action, an "and" action and a "leaps" action. The pictograms inside the boxes indicate the characteristics of each action. The solutions for each "transitions" and "leaps" actions have to be separately composed by each performer. The "and" actions are to be composed collectively (SMITH, 1993, p. I).

Fig. 2 - Transitions and Leaps, by Stuart Saunders Smith, first page.

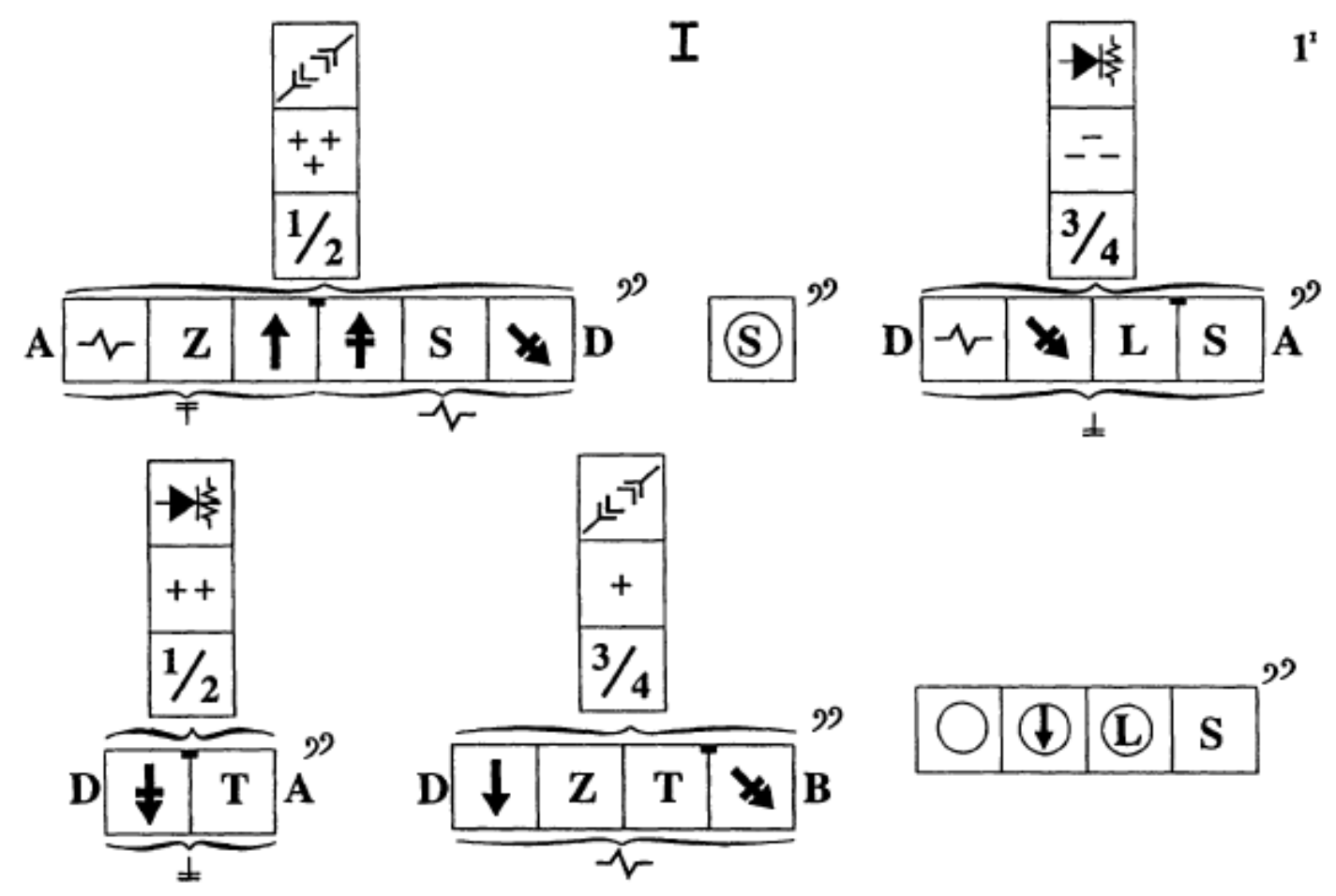

Copyright Sonic Art Editions. Used by permission of Smith Publications, Sharon, VT 05065 USA 
The score of a trans-media system does not present a finished composition; rather, it consists of graphic schemes-pictograms placed inside boxes-that provide instructions for performers to create their own music collectively or individually. Performers may include artists from other performing and visual arts practices. Therefore, Smith celebrates a unified reality of co-composition that recognizes the creative mind of the other and asks (requires) performers of any discipline to perform together.

By featuring process, the trans-media system cannot be considered an open-ended experiment. There is no attempt to suppress Smith's input; rather, his input is in the process. Smith (WELSH 1995, p. 140) discusses this subject in the following statement:

\begin{abstract}
For me, certain kinds of so-called graphically notated scores have become, over the years, less and less interesting because they possess almost no structural integrity. These systems are so open that such pieces are unrecognizable from performance to performance. Of course in the case of John Cage, he celebrates that situation. He finds the poetry of absence delightful. I, on the other hand, am not looking for absence, but rather a refinement and continual transformation of my taste-the I. So I try to build into my collective compositional works my taste in process. This taste in process takes on the structural characteristic of a recognizable entity regardless of medium. This, at once fixed, yet always changing landscape is the I-me an infinity within a finite space-the poetry of being present!!
\end{abstract}

The attitude of grounding the "I" on a balance between the "fixed" and the "changing" landscape is suggestive of Smith's reconciliation of Emerson's and Thoreau's attitudes? Whereas the reference to "fixed" denotes an Emersonian attitude of letting his own creative mind guarantee his compositional imprint, "changing” denotes a Thoreauvian call for transformation through self-development ("a refinement and continual transformation of my taste”). Moreover, Smith's reference to "changing” indicates that he lets his transform itself alongside performers. During his years working with a collegiate contemporary music ensemble, Smith had the chance to present the trans-media systems on many occasions. In each performance, a symbolic unity emerged from the equalization of performer and composer roles. And by working alongside the performers, Smith himself bettered his artistry.

Nevertheless, Smith's creative mind is still the driving factor of the symbolic unification of composer and performers. The "experiment" in the trans-media systems is Emersonian because Smith's idiosyncratic process guarantees that his artistic voice is heard. But the score's focus on process does not render the work to be formalist. While these systems guarantee Smith's compositional imprint by providing a pre-compositional system to the performers, the performers are the co-composers of the final product. The trans-media system is an endeavor towards unification of the performer, composer, and the arts in general, rather than an attempt to have the performers "parrot" Smith's thinking. There is no hierarchy; performers and composers are equally vital, and the provision of process is necessary to promote this unity. This balance of the composer's self with the acknowledgment of the other as part of a totality is one of the defining attitudes of New England Transcendentalism.

\title{
3.3.2.2 Mobile compositions and co-existence music
}

Mobile compositions are works in which Smith grants the performers freedom to handle material, by providing collections of melodies with no set order and no obligation of playing all melodies, thus creating an open-form piece. Players learn the melodies and 
perform them as a communal improvisation in which not only the order, but also tempi and dynamics may be up to their discretion. Since the performers are encouraged to interact, the melodies do not interact by chance, but according to the performers' will. The openness of all the aforementioned parameters translate Smith's endeavor to level the roles of performer and composer that suggests his unification effort.

The following example shows two musical sections ("A" and "B") of the mobile Notebook (1980). Each section is formed by a variety of phrases that are separated by single or double commas. A double comma indicates a longer pause than a single comma. As the score asks, each performer decides in real time the "dynamics, tempo, articulation, and phrasing" of each event. He states that the notated dynamics are mere suggestions. Each performer also decides the order and the amount of events he or she is going to perform. The instrumentation of Notebook is completely free:

Fig. 3 - Notebook, by Stuart Saunders Smith, first page.

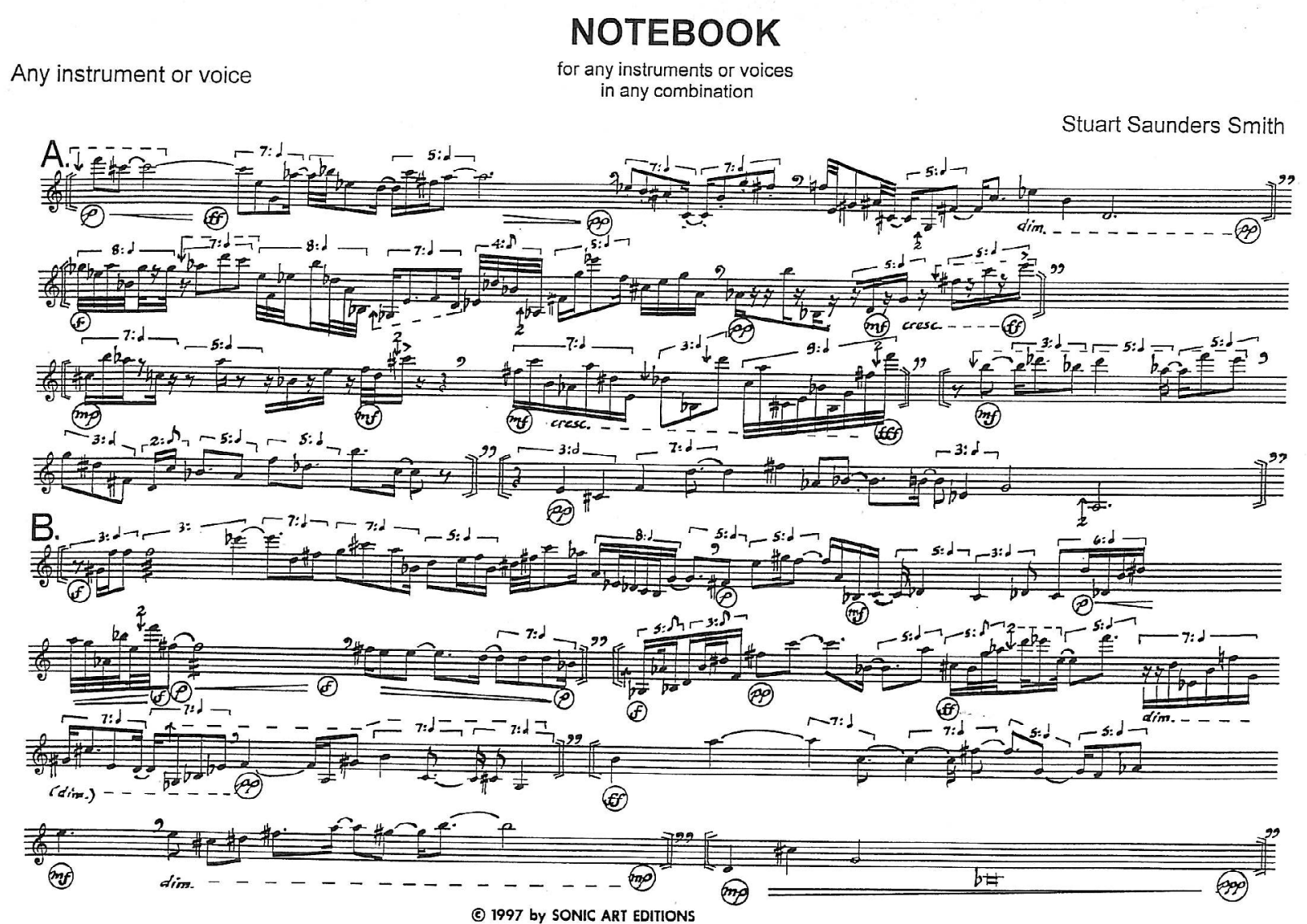

Copyright Sonic Art Editions.Used by permission of Smith Publications, Sharon, VT 05065 USA

Over time, Smith's musical mobiles evolved into a sub-genre he calls "music of coexistence." He composed his first co-existence mobile, Part, in response to the daily reality of the performer. Performers spend hours perfecting their skills, much like how a composer writes music. In his traditional mobiles, performers interacted by making decisions about tempo, intensity, and character. However, in music of co-existence, performers do not attempt to interact, so that each part is a rhythmically intricate solo that resultingly builds an extremely complex polyphony. This process is analogous to the intrinsic paradox of the Transcendentalist movement: the path to social harmony happens through individual freedom. 
More recently, Smith has composed co-existence pieces that do not fit in the mobile category. In A River, Rose (2005) for violin and vibraphone, there is no interaction between the parts. Even though there is no score, only individual parts, the juxtaposition of the first 8 measures of each part illustrates how the material avoids a chamber music-like interaction:

Fig. 4 - A River, Rose, by Stuart Saunders Smith, first 8 measures.

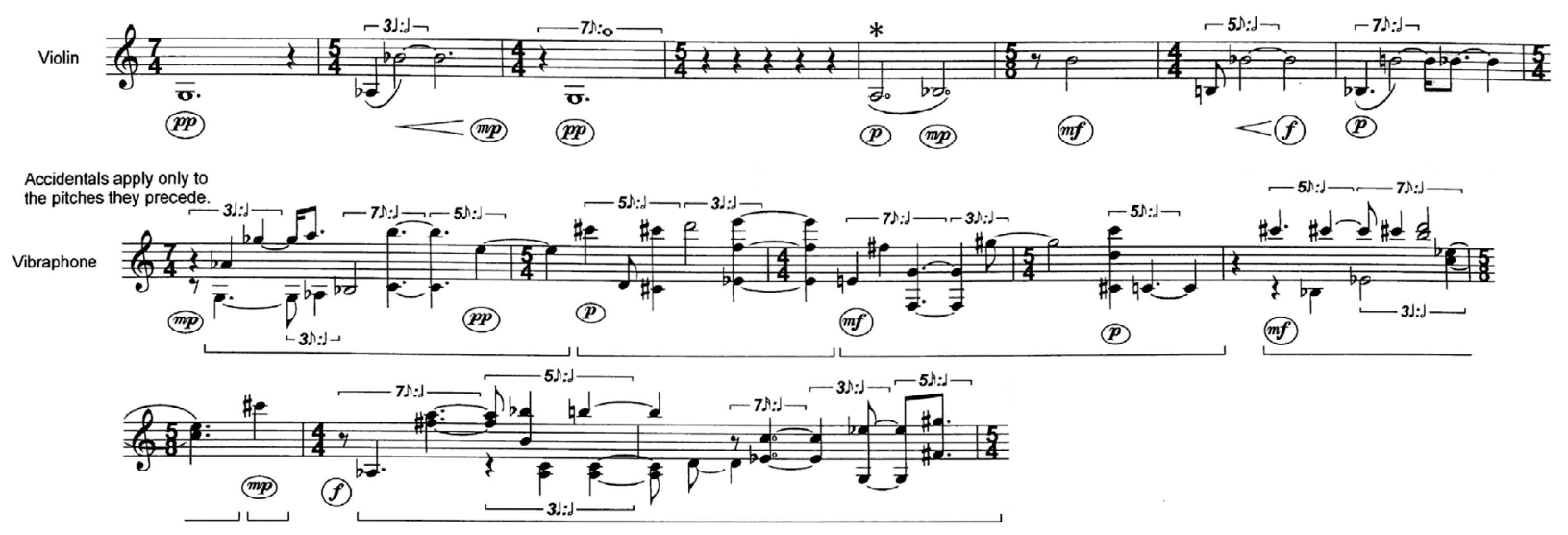

Copyright Sonic Art Editions.Used by permission of Smith Publications, Sharon, VT 05065 USA

The intricate polyphony that results from the performance of a co-existence piece does not depend solely on the composer, but comes through a multi-layered coalition of forces: the composer contributes complex melodic and rhythmic vocabulary in particular and the performers contribute their choices of "when" and "how." The performers also contribute by interacting in countless ways, inadvertently or not, hence adding complexity to the polyphony.

There is a kind of inevitability present in Smith's discourse regarding this complexity that surpasses the dichotomy of dualistic versus non-dualistic. Complexity is not a mere idea, because it does arise from formalism. As often as contradictions happen within the writings of Transcendentalists, Smith's music bridges the gap between dualism and nondualism: at the same time that it symbolically reflects his life stances, it is an inseparable part of the universe's complexity. Complexity emerges in his music through his and the performers' experiences. It also materializes in the unpredictability of the performance act. Smith's music does not merely allude to complexity; in his understanding, it is complexity:

I am not interested in the idea of complexity

I am interested in complexity. (SMITH, 2014, p. 232)

\subsubsection{Here and There}

In Here and There (1972) for piano interior, short-wave radio, and any melody instrument, Smith inspires audiences and performers to transform. In the piece's program notes, Smith (1971, preface) proposes an "exploration of inner-outer space" in which performers can "transform themselves, others, and the environment into a unified landscape." Smith's explanation of how Here and There inspires the emergence of a "unified landscape" is partially applicable to his mobiles and co-existence pieces: "Here and There levels the relationship of time and space and performer, composer, audience. . . . The composer invites rather than dictates. The performer has direction and is relatively free. The audience must make music out of this unusual sound collage, unified and diverse. Common-union-ism" (SMITH, letter to the author, 2015). 
The second half of this convoluted statement implies that the piece inspires unification by leaving choices up to the performers and by inviting the audience to "make sense" of the polyphony resulting from the performance act, like in the mobiles and coexistence music. All the parts are written with ideographic notation, similar to that of the trans-media systems. Additionally, there are seven traditionally written melodies, labeled with numbers one through seven. The ideographic chart for the melody instrument shows signals indicating actions such as "imitate," "blend," or "repeat," and numbers indicating each of the seven melodies. In the boxes that do not contain numbers, the performer has the freedom to improvise. The two other instrumental parts are also partially free and both are written exclusively with ideographic notation. However, while the short-wave radio features ideograms that indicate dynamic, repetition, duration or "all parameters of an event are left to the discretion of the performer," the ideograms of the piano interior direct the performer to "imitate" or "blend" with the other parts. The three parts feature a colon sign that designates "all parameters of an event are left to the discretion of the performer." This freedom of improvisation is indicative of a unification of the roles of performers and composer. The example below shows the ideographic notation:

Fig. 5 - Here and There, by Stuart Saunders Smith, melody instrument part.

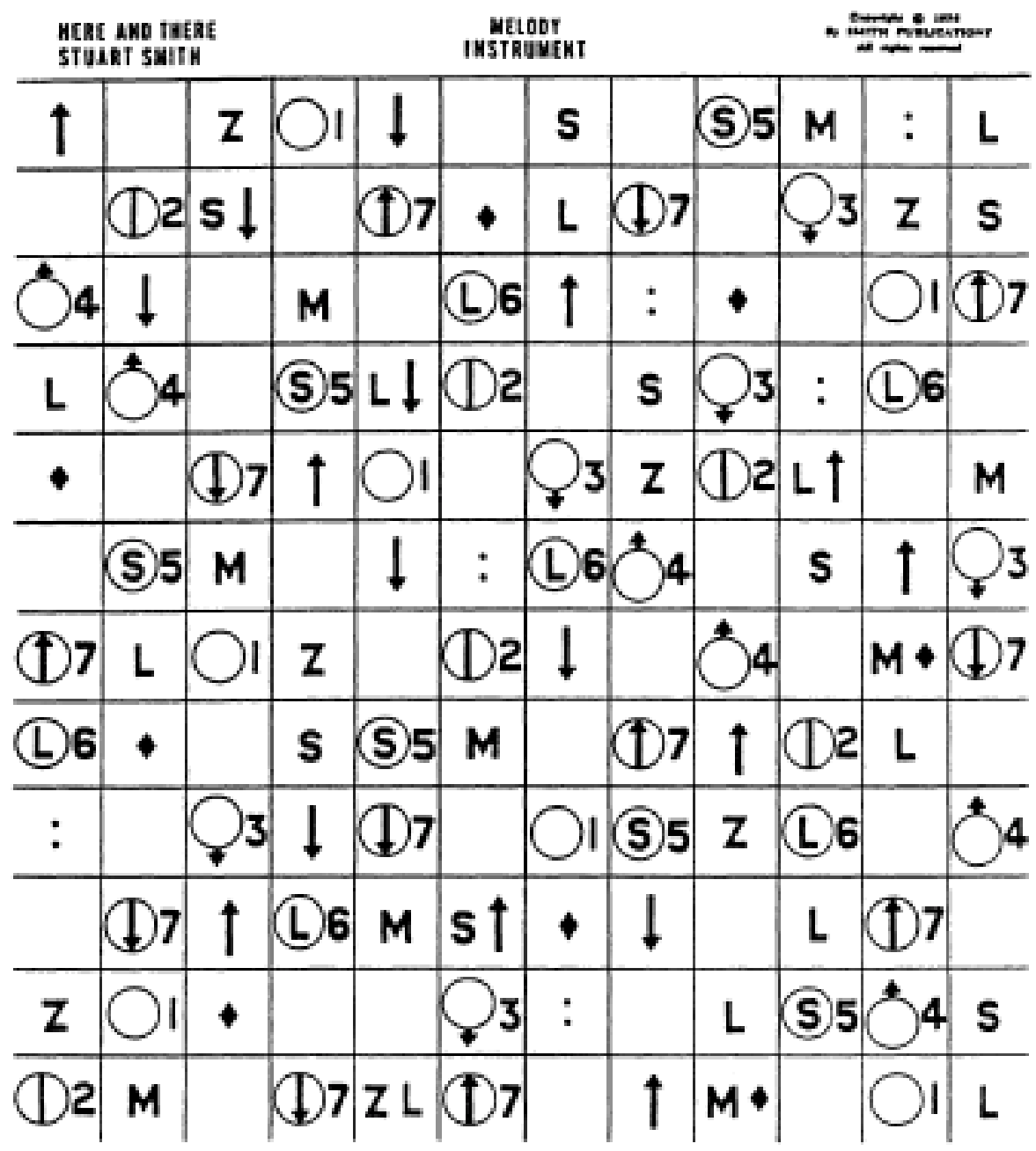

Copyright Sonic Art Editions.Used by permission of Smith Publications, Sharon, VT 05065 USA 
Beyond leveling the roles of performers and composer, how does Here and There incorporate the transformation of "the environment" in its performance process? The answer lies in the short-wave radio part, as Smith implies: The "far off" sounds caught by the radio may be happening "at different times [and spaces] than the performance time and space" (SMITH, letter to the author, 2015). However, the performance has the power of bringing and merging these different times and spaces into the performance setting.

Each of the words in the piece's title, as Smith explains, is related to one of the trio's partakers: "here" refers to the melody instrument, "and" refers to the piano interior, and "there" refers to the short-wave radio. The melody is represented by the word "here," because it indicates the most palpable, traditional aspect of the "experiment." The word "and" suggests the piano interior part, not only because it bridges melody and the ambient sounds coming from the radio, but also because it merges tradition (piano) and experimentalism (extended techniques). Because the radio part "picks up cultural found objects out there" (WELSH 1995, p. 57), it functions as symbol of our condition of unity. As Smith states: "Here: the inside God (melody instrument); And: the unifier, the connector (piano interior); There: the other, the stranger, the far away place (short-wave radio)" (SMITH, letter to the author, 2015). Thus, performers and the composer realize their state of Oneness while the interaction of parts symbolizes a unification of the musical space. Most importantly, however, both of these conditions of Oneness are inserted in a landscape that unifies music and the universe (i.e. time and space) via the short-wave radio part.

Finally, in Here and There, Smith corroborates his anti-nationalism and pacifism by highlighting these stances as vital for unification: "When performed or studied [Here and There] leads to an anti-nationalist universe where all are made welcome in the space of Here and There. By analogy, this system of improvisation is a political gesture and creates cells, in this case the trio of revolution, gentle + beautiful; not violent and abusive" (SMITH, letter to the author, 2015). Here and There is thus an affirmation that Smith's music always reveals different layers of Transcendentalist thought. It is virtually impossible to fit each of his pieces into a single category. Here and There not only unifies composer, performer, and audience into Oneness; by conveying his anti-nationalistic and pacifist stances; it also unifies Smith with his art.

\section{CONCLUSION}

As idiosyncratic as Smith's music is, it is inserted in a lineage of thought that traces back to the Transcendentalists: facing erudition critically while having freethinking and free agency as life's essence. The apparent paradoxes posed by being an academic while critiquing academicism are present in both the Transcendentalists and Smith. His work dialogues aesthetically with the full spectrum of the Transcendentalist thought: from the sensorial to the symbolic, from self-abnegation to personal imprint, from open-endedness to purpose. His balance between applying "listening to the inner" and "listening to the sound's intelligence" corroborates how these attitudes coalesce in his work. Whereas "inner listening" plays the important role of letting his experience speak through itself, "staying out of the way" is Smith's approach to exercising self-abnegation when composing a new piece.

Smith's music symbolizes universal unity by unifying his art with his pacifist stance and by alluding to Oneness. Here and There for instance, uses openness to create an intricate atmosphere that promotes pacifism and conveys Oneness. While his music levels his role with those of the performer and audience, both symbolically and practically, his 
attitude of deliberately writing music that is allusive to his beliefs shows a precedence of the inner over outer akin to that of the Transcendentalists. When music seeks to transform composer, performers, and audience into a "unified landscape," it manifests the universal spirit. But in Smith's music, this spirit is emanated by the individual, as shown in the predominance of his creative mind in the rhythmic intricacy of As if Time Would Heal by its Passing or in the provided procedure of Transitions and Leaps. This balance of the self and the whole is the poetry of being present while bowing to the totality.

\section{Notas de fim}

1 Although Smith does not use these very words, this notion is recurrent in his interviews and musicological writings. 2 In the pages that follow, I will apply the terms "Oneness," "universal soul," and "universal spirit" interchangeably.

3 I have decided to keep Smith's original formatting. Like his poetry, Composing Thoughts features short stanzas that are frequently intercalated by dots that are to be read as one second of silence each.

4 In this passage Berman referred specifically to the idealism of Kantian philosophy in terms of art. It seems, however, suitable to Smith's discourse.

5 Smith has categorized his music in slightly different ways throughout the years. One example of how Smith does this can be found in: Stuart Saunders Smith, program notes, "Making Sense out of My Music," concert At Sixty (Akron, OH: University of Akron, March 7-8, 2008), 6-7. The First time he refers to coexistence music, although using the label "music of isolation" can be found in: Stuart Saunders Smith, “To Suffer Music," Perspectives of New Music 34, no. 1 (Winter 1996), 112. A recent example of Smith's use of the "co-existence" label can be found in: Smith, "Composing Thoughts," 236.

\section{BIBLIOGRAPHY}

BERMAN, Art. Preface to Modernism. Urbana: University of Illinois Press, 1994.

BUELL, Lawrence, ed. The American Transcendentalists: Essential Writings. New York: Modern Library, 2006.

CAGE, John. "On Silence.” YouTube video from an interview realized in New York. April 02, 1991. https://www.youtube.com/watch?v=pcHnL7aS64Y.

EMERSON, Ralph Waldo. The Collected works of Ralph Waldo Emerson. Edited by Alfred R. Ferguson. Cambridge: Harvard University Press, 1971.

- Essays and Lectures: Nature: Addresses and Lectures / Essays: First and Second Series / Representative Men / English Traits / The Conduct of Life. Edited by Joel Porte. New York: Library of America, 1989.

"War." In The Works of Ralph Waldo Emerson. Vol. 11, Miscellanies, edited by J. E. Cabot, 177-201. Boston: Fireside Edition, 1909.

FALVO, Rob. "Stuart Saunders Smith's 'Ground' for Solo Glockenspiel Clear Complexity.” Percussive Notes 49, no. 3 (May 2011): 43-49.

FRONTHINGHAM, Octavius Brooks. Transcendentalism in New England: A History. New York: G.O. Putnam's Sons, 1876.

IVES, Charles. "Essays Before a Sonata." In Three Classics in the Aesthetic of Music, 104-185. New York: Dover Publications, 1962.

LACERDA, José "Zeca." "The Silence... An Introduction to the Inner World of Stuart Saunders Smith.” Percussive Notes 50, no. 6 (November 2012): 40-47. 
MEYER, Leonard B. Music, the Arts, and Ideas: Patterns and Predictions in Twentieth-century Culture. Chicago: University of Chicago Press, 1969.

MULLER, Jeremy. "Amidst the Noise: Stuart Saunders Smith's Percussion Music.” Percussive Notes 52, no. 4 (July 2014): 6-15.

SACKS, Kenneth S. Understanding Emerson: 'The American Scholar' and his struggle for selfreliance. Princeton: Princeton University Press, 2003.

SCHICK, Steven. "Learning to Fly: A Particular Kind of Balance." Notes to Stuart Saunders Smith: The Links Series of Vibraphone Essays. New World Records, CD 80690-2, 2009.

SHULTIS, Christopher. Silencing the Sounded Self: John Cage and the American Experimental Tradition. $2^{\text {nd }}$ ed. Lebanon, NH: University Press of New England, 2013.

SMITH, Stuart Saunders. “Against Definition.” Perspectives of New Music 32, no. 1 (Winter 1994): 214-218.

—. As if Time Would Heal by its Passing. Baltimore: Smith Publications, 1991.

—. "A Composer's Mosaic." Perspectives of New Music 22, no. 1/2, (Autumn 1983 - Summer 1984): 275-285.

—. “Composing Thoughts.” In The Modern Percussion Revolution: Journeys of the Progressive Artist, edited by Kevin Lewis and Gustavo Aguilar, 224-283. New York: Routledge, 2014.

—. “Geography of Time: The Links Series of Vibraphone Essays (1974-1994).” Percussive Notes 32, no. 1, (April 2005): 58-63.

—. Here and There. Baltimore: Smith Publications, 1972.

—. "Interview with Stuart Saunders Smith.” By Jude Traxler. Ex Tempore 14, no. 1 (Spring/ Summer 2008). http://www.ex-tempore.org/traxler.htm.

—. Notebook. Baltimore: Smith Publications, 1997.

—. A River, Rose. Baltimore: Smith Publications, 2005.

—. "To Suffer Music,” Perspectives of New Music 34, no. 1 (Winter 1996): 106-114.

—. Transitions and Leaps. Baltimore: Smith Publications, 1990.

THOREAU, Henry D. Walden. New Haven: Yale University Press, 2006.

WELSH, John P. The Music of Stuart Saunders Smith. New York: Excelsior, 1995.

—. "Stuart Smith's 'Links' Series,” Percussive Notes Research Edition 21, no. 3, (March 1983): 75-89. 
José Augusto Duarte Lacerda, percussionista, doutor em música contemporânea pela Bowling Green State University (Ohio, EUA), com ênfase em performance de instrumentos de percussão, mestre em performance musical pela University of Miami (2011, Florida, EUA) e bacharel em música pela Universidade Federal de Santa Maria (2008), com ênfase em performance de instrumentos de percussão. É professor de percussão da Universidade Federal de Mato Grosso, onde fundou e coordena o programa de extensão [re]Percute UFMT. Integra também o grupo de música contemporânea Abstrai Ensemble. Sua experiência orquestral inclui, mas não se limita a, passagens como membro da Orquestra Sinfônica Brasileira Jovem, Orquestra Sinfônica da UFRJ e Orquestra Acadêmica do Festival de Inverno Campos de Jordão. Também já atuou como músico convidado com orquestras como a Orquestra Sinfônica Brasileira, a Orquestra Petrobras Sinfônica a Firebird Chamber Orchestra (EUA), dentre outras. Sua experiência como músico de câmara inclui passagens onde trabalhou pessoalmente com compositores como Bob Becker, Christian Wolff, Elliott Sharp, George Lewis, Gabriela Ortiz, James Romig, Jeff Herriott, John L. Adams, Lewis Nielson, Roberto Victorio, Thomas DeLio, Steve Reich, Stuart Saunders Smith, dentre outros. Em diversas ocasiões, estreou obras de alguns destes compositores. Publicou artigos nos periódicos Per Musi, Percussive Notes e Rhythm! Scene, e gravou diversas obras, incluindo seu álbum contendo obras para vibrafone solo, lançado pelo selo SoundSet Recordings. 